University of South Florida

DIGITAL COMMONS

Digital Commons @ University of

@ UNIVERSITY OF SOUTH FLORIDA

South Florida

School of Geosciences Faculty and Staff

Publications

School of Geosciences

2-1996

\title{
Geometry of Continental Normal Faults: Seismological \\ Constraints
}

Jochen Braunmiller

Oregon State University, jbraunmiller@usf.edu

John L. Nabalek

Oregon State University

Follow this and additional works at: https://digitalcommons.usf.edu/geo_facpub

Part of the Earth Sciences Commons

\section{Scholar Commons Citation}

Braunmiller, Jochen and Nabalek, John L., "Geometry of Continental Normal Faults: Seismological Constraints" (1996). School of Geosciences Faculty and Staff Publications. 828.

https://digitalcommons.usf.edu/geo_facpub/828

This Article is brought to you for free and open access by the School of Geosciences at Digital Commons @ University of South Florida. It has been accepted for inclusion in School of Geosciences Faculty and Staff Publications by an authorized administrator of Digital Commons @ University of South Florida. For more information, please contact digitalcommons@usf.edu. 


\title{
Geometry of continental normal faults: Seismological constraints
}

\author{
Jochen Braunmiller and John Nábĕlek \\ College of Oceanic and Atmospheric Sciences, Oregon State University, Corvallis
}

\begin{abstract}
Teleseismic body waves from large earthquakes are used to study the downdip geometry of continental normal faults in the Aegean. Waveform modeling techniques together with rigorous statistical tests are applied to put firm bounds on the amount of downdip curvature of these faults and the role of coseismic slip on a basal detachment. Synthetic modeling shows that good azimuthal station coverage and inclusion of $\mathrm{SH}$ waves are necessary to resolve fault curvature. The data indicate ruptures of the Aegean events occurred on planar faults extending across the entire brittle portion of the crust. No seismogenic low-angle detachment faulting at the base of the upper crust was detected for these events. Decoupling of the brittle upper crust from the plastic lower crust probably occurs aseismically in a ductile fashion.
\end{abstract}

\section{Introduction}

The mechanisms of continental crust extension are a matter of intense discussion within the geoscience community. In this paper we present seismological constraints on the downdip geometry of continental normal faults.

Drawing primarily from evidence from geologic mapping and reflection seismology, various continental extension models, including pure shear, simple shear, or a combination of both, have been proposed. Pure shear extension has been described in terms of "bookshelf models" involving stacks of blocks separated by planar high-angle normal faults [Morton and Black, 1975; Wernicke and Burchfiel, 1982; Jackson and McKenzie, 1983] or in terms of listric faults bottoming onto a basal detachment [Hamblin, 1965; Davis et al., 1980]. Lowangle normal faults of large areal extent, so-called "detachment faults", were first described and extensively studied in the metamorphic core complexes of the Basin and Range region [e.g., Crittenden et al., 1980]. Wernicke [1981], Davis [1983], and Lister et al. [1986] suggested these gently dipping structures are fault surfaces caused by simple shear extension. This interpretation aroused considerable controversy since rock mechanics precludes low-angle faulting in the presence of a subvertically oriented maximum stress axis [e.g., Sibson, 1985]. More recently, Spencer and Chase [1989] and Melosh [1990] argued principal stress orientation may change with depth to that favoring initiation of gently dipping shear zones. The rotation of fault surfaces to low dip angles due to isostatic response has been investigated by Buck et al. [1988], Buck [1988], and Wernicke and Axen [1988]. Forsyth [1992] addressed the influence of topographic loads and bending stresses on slip continuation for faults with various dips.

Seismological data from large earthquakes provide constraints on the geometry of active normal faults against which the kinematic, rock mechanical, and numerical models can be tested. Most previous investigations of downdip curvature of normal-faulting earthquakes compared the fault dip at the

Copyright 1996 by the American Geophysical Union.

Paper number 95JB02882.

0148-0227/96/95JB-02882\$05.00 surface with the dip at a greater depth indicated by fault plane solutions from $P$ wave first-motion polarities or point source modeling of long-period waveforms. Generally, these comparisons suggest steeply dipping planar faults [e.g., Doser, 1986; Jackson and White, 1989; Doser and Smith, 1989]. However, J.L. Nábělek's (Planar versus listric faulting: The rupture process and faulting geometry of the 1983 Borah Peak, Idaho earthquake from inversion of teleseismic body waves, submitted to Journal of Geophysical Research, 1995, hereinafter referred to as Nábělek, submitted manuscript, 1995) study of the 1983 Borah Peak, Idaho earthquake, is the only study to include formal waveform inversion in which fault curvature is explicitly parameterized. The Lost River fault, on which this earthquake occurred, was found to be planar, in agreement with geodetic inversion by Stein and Barrientos [1985] and Barrientos et al. [1987]. No evidence for coseismic slip on a detachment was discerned. A motivation for the search for a coseismic slip on a basal detachment came from Eyidogan and Jackson's [1985] $P$ wave modeling of the 1969 Alasehir and the $1970 \mathrm{Gediz}$ earthquakes in Turkey, which suggested significant seismic slip on a low-angle midcrustal detachment induced by the steeply dipping ruptures.

In this paper we apply Nábělek's (submitted manuscript, 1995) body wave inversion technique to study the fault geometry of the six largest normal-faulting earthquakes in the last 25 years in the Aegean region (Figure 1). We reexamine the Alasehir and Gediz events. First, we present a synthetic example to show the effect of fault geometry on teleseismic waveforms, followed by a description of the inversion procedure and application to actual data.

\section{Synthetic Example}

Waveshapes and amplitudes of teleseismic body wave seismograms for magnitude 6.5-7 earthquakes are generally well accounted for with average (point source) models; effects of fault curvature are only secondary. To determine what phases and recording stations are most sensitive to fault geometry, we calculate synthetic seismograms for finite fault models with various curvatures. These models consist of three subsources placed at 10,6 , and $2 \mathrm{~km}$ depth. We assume pure normal-faulting on a north-south striking, eastward dipping 


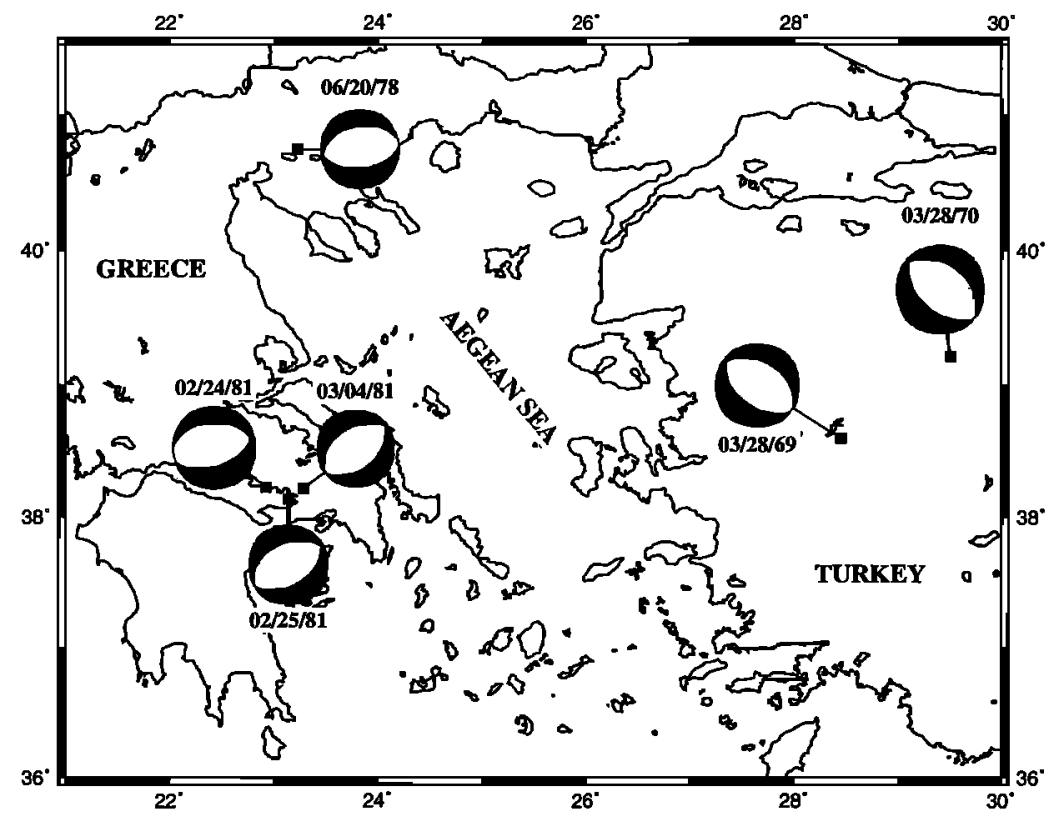

Figure 1. Map of the Aegean region. Squares mark epicenters of earthquakes studied; size of fault plane solutions (lower hemisphere projections) is proportional to the seismic moment.

fault. The rupture nucleates at the bottom and propagates upward. Figure 2 compares seismograms for planar (solid line) and listric (dashed line) models. For the planar model each subsource has a $45^{\circ}$ dip, while the listric model has a $40^{\circ}$ upward concave curvature $\left(25^{\circ}, 45^{\circ}\right.$, and $65^{\circ}$ dip of the $10-, 6-$, and $2-\mathrm{km}$ subsources, respectively). The stations are distributed in even, $30^{\circ}$ azimuthal intervals and cover the typical distance range used in teleseismic body wave modeling.

Teleseismic $P$ and (not shown) $S V$ waveshapes are not very sensitive to downdip fault curvature. The presence of noise, uncertainties in instrument responses, and local site conditions can obscure the small predicted differences in amplitude. Substantially larger is the effect of downdip geometry on the polarities and amplitudes of $S H$ waves. The largest effect is observed along strike ( $0^{\circ}$ and $180^{\circ}$ azimuth) and at neighboring azimuths $\left(30^{\circ}, 60^{\circ}, 120^{\circ}\right.$, and $150^{\circ}$ azimuth $)$. These stations are near the radiation nodes, and as the rupture propagates up along a curved fault, the wave polarities reverse thus strongly affecting the waveforms. In contrast, teleseismic $P$ and $S V$ waves for normal faults are antinodal. Their amplitudes do not vary appreciably with azimuth and takeoff angle.

The above example shows good station coverage and sensitive statistical tests are required to detect small amplitude variations caused by fault curvature. It is crucial to include $S H$ waves, since their waveforms are most sensitive to changes in fault dip.

\section{Data and Inversion}

Our data consist of short- and long-period $P$ and $S$ wave seismograms recorded in the $30^{\circ}-90^{\circ}$ epicentral distance range by the World-Wide Standardized Seismic Network (WWSSN) and the Global Digital Seismic Network from the largest $\left(M_{w} \geq\right.$ 6.2) normal-faulting earthquakes in the Aegean (Alasehir, 1969; Gediz, 1970; Thessaloniki, 1978; and the three largest earthquakes of the 1981 Corinth series). These earthquakes caused surface ruptures and were probably strong enough to rupture the entire brittle part of the crust. For all events we use data from at least 25 azimuthally well-distributed stations.
Following Nábělek (submitted manuscript, 1995), the analysis consists of three steps (Figure 3). First, we obtain the earthquake's point source model [Nábĕlek, 1984]. The point source describes the average faulting process (i.e., rupture's centroid depth and the average dip); for an earthquake whose rupture reached the surface, the vertical rupture extent is roughly twice the centroid depth. We use the point source model to construct appropriate models for testing geometric complications.

Second, we investigate presence of coseismic slip on a subhorizontal detachment at the fault base. This is achieved by introducing a second source at twice the centroid depth (Figure 3 ) constrained to have a low $\operatorname{dip}\left(0^{\circ}\right.$ or $\left.10^{\circ}\right)$ thus mimicking a detachment fault. We invert for moment release immediately following the main body wave pulse while keeping the other parameters fixed. Significant coseismic slip on a detachment would appear as moment release associated with the second source.

Finally, we provide formal statistical bounds on the amount of fault curvature associated with these earthquakes. We divide the fault surface evenly into three parts and place one point source (subsource) in the middle of each part (Figure 3). A finer subdivision could lead to an overparameterization and instability; three subsources are sufficient to find the overall fault geometry. Teleseismic body waves are not sensitive to relative horizontal position of the subsources [Braunmiller, 1991] and therefore placing the subsources on a planar fault (using the dip angle found in step one) is adequate for the purposes of this study. Rupture is assumed to propagate upward from the base of the seismogenic crust as typically observed [Sibson, 1982; Das and Scholz, 1983; Wallace and Kemeny, 1992]; upward propagating rupture is represented by a slight delay of the two shallower subsources relative to the deepest one.

Clearly, the best fitting model for each earthquake would be obtained by freeing all model parameters during the inversion. This would, however, make the significance of each parameter difficult to interpret due to complex parameter trade-offs. 

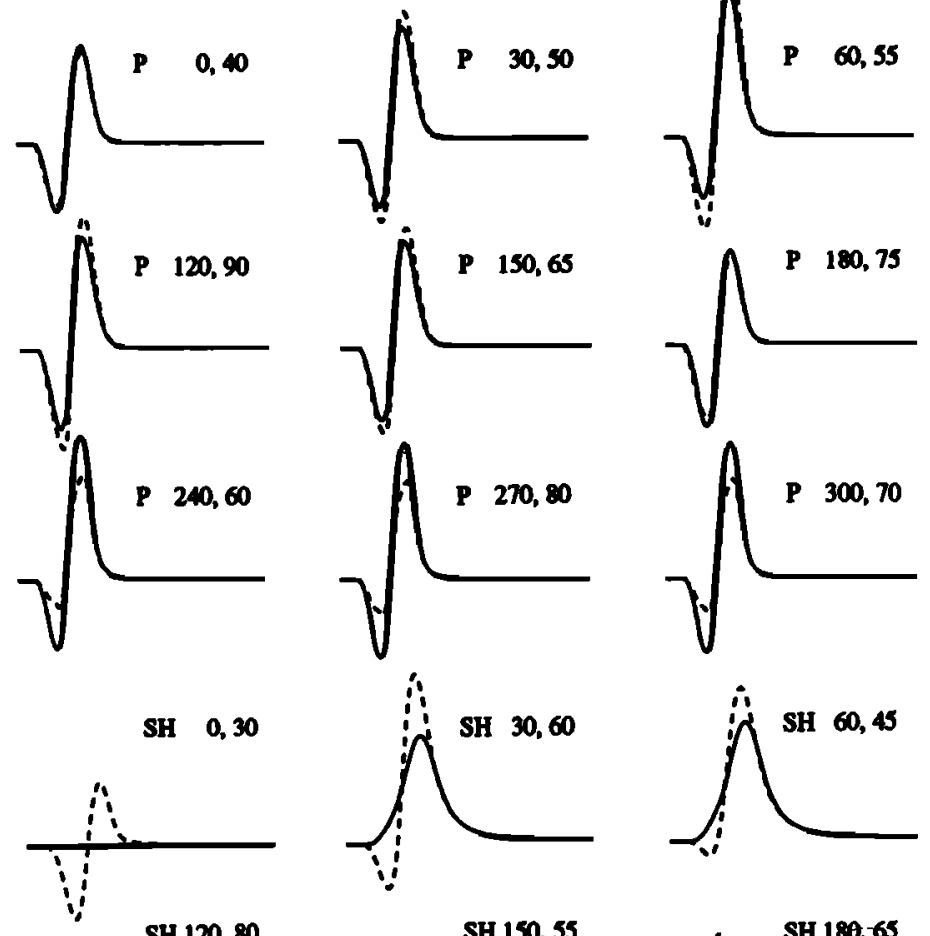

$\mathrm{SH} 150,55$
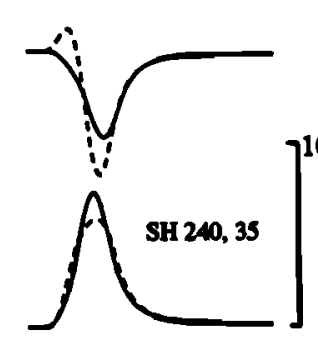

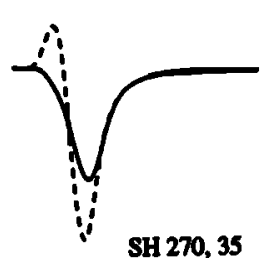

SH 270, 35
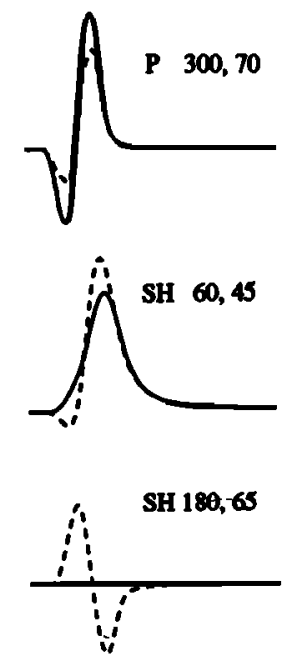

SH 300,40

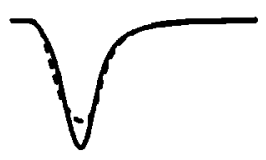

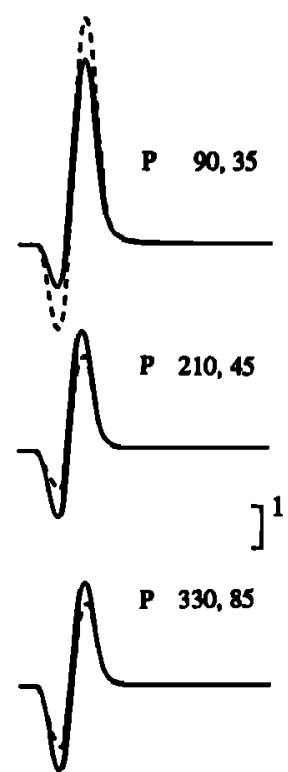

SH 90,35

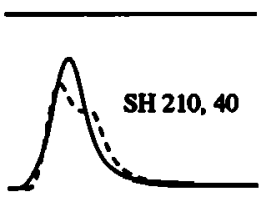

SH 330,45

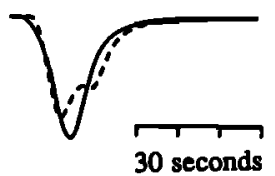

Figure 2. Effects of fault curvature on teleseismic waveforms. Solid lines indicate planar model; dashed lines indicate listric model ( $40^{\circ}$ concave upward curvature). P signifies $P$ waves, SH signifies $S H$ waves. Numbers give azimuth relative to fault strike and epicentral distance (specifying the ray parameters), both in degrees. The crustal model, as in actual analysis, is a half-space with a compressional velocity of $6 \mathrm{~km} / \mathrm{s}$, shear velocity of $3.5 \mathrm{~km} / \mathrm{s}$ and density of $2800 \mathrm{~kg} / \mathrm{m}^{3}$. The attenuation parameter $t^{*}$ is $1 \mathrm{~s}$ for $P$ waves and $4 \mathrm{~s}$ for $S H$ waves. Seismogram amplitudes are normalized to an epicentral distance of $40^{\circ}$.
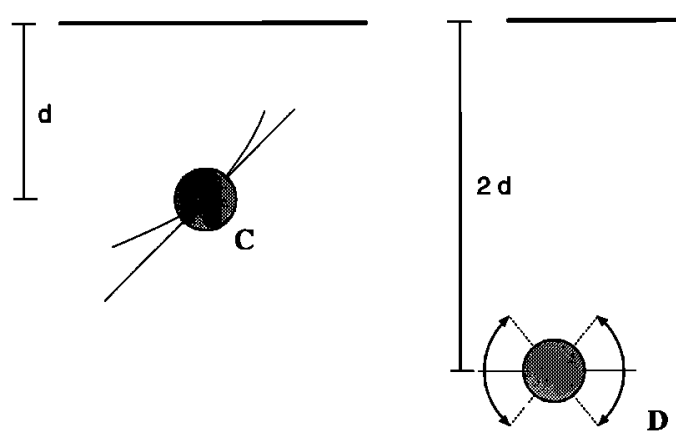

C: centroidal source
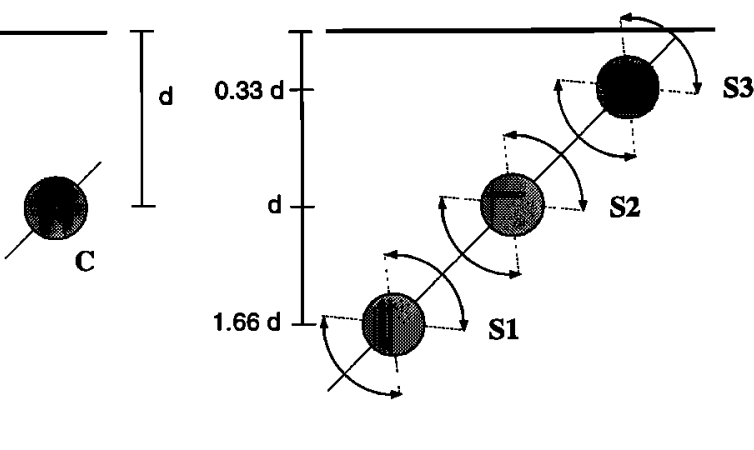

Figure 3. Relationship between the three model parameterizations used to infer fault geometry. (left) Average (centroidal) model: a single point source with all parameters free. (middle) Detachment model: a twosource model comprised of the centroidal source and a detachment source (only moment release of the detachment source is determined). (right) Three-source model (S1, S2, and S3) for determining fault curvature: source mechanisms, positions, and curvature are prescribed, source time functions are free, and models with different curvature are compared statistically. The "d" indicates centroid depth. 

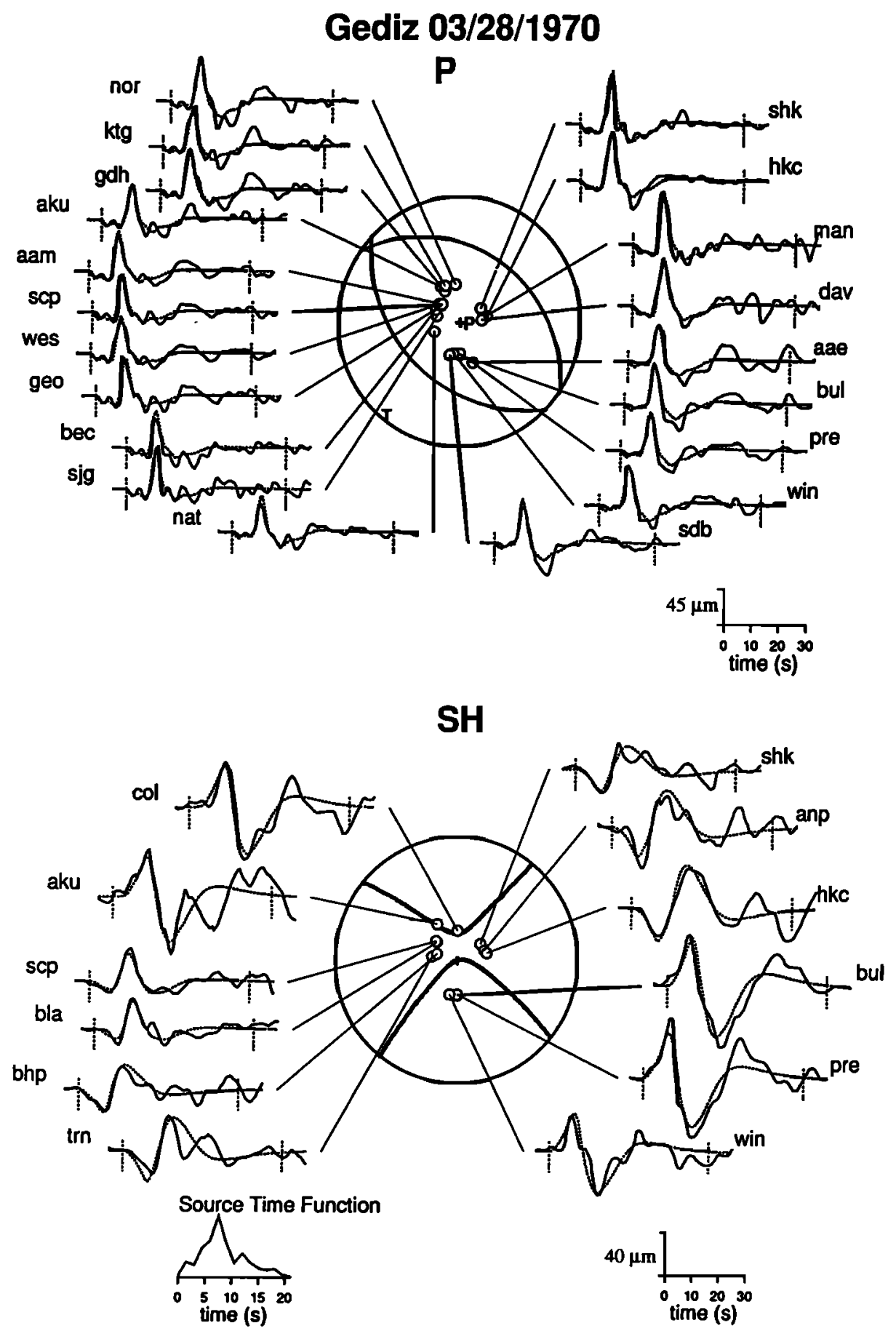

Figure 4. Point source $P$ and $S H$ waveform fit for the Gediz earthquake. Solid lines indicate observed seismograms; dashed lines indicate synthetic seismograms. $P$ and $S H$ radiation patterns and focal-sphere ray projections (lower hemisphere) are shown. The source time function is shown in the lower left. Seismogram amplitudes are normalized to an epicentral distance of $40^{\circ}$.

Instead, we chose a parameterization that, with the minimum of free parameters, allows us to compare statistically models with different amounts of curvature prescribed. Fault curvature is simulated by preassigning the dip to each subsource. Strike, rake, and seismic moment of the subsources follow the point source estimates and are fixed during inversions. The combined moment tensor of the three subsources is constrained to reproduce the point source solution, assuring that the changes in fit for different models are not caused by departures from the average model. Only the shape of the source time function (rate of the moment release) for each of the subsources was allowed to vary. Thus the only geologically significant difference between the models we tested was the amount of curvature. In the subsequent discussion a $20^{\circ}$ concave upward curvature" means that the dip of the bottom subsource is $10^{\circ}$ smaller and the dip of the top subsource is $10^{\circ}$ larger than the dip of the intermediate source (i.e., dips $1=35^{\circ}$; $\operatorname{dips}_{2}=45^{\circ}$; $\operatorname{dip}_{3}=55^{\circ}$, Figure 3 ); the dip of the intermediate source is prescribed to equal the initial point source estimate.

Differences between models are difficult to quantify by naked eye. The significance in misfit differences between different models is investigated statistically using a $t$ test 

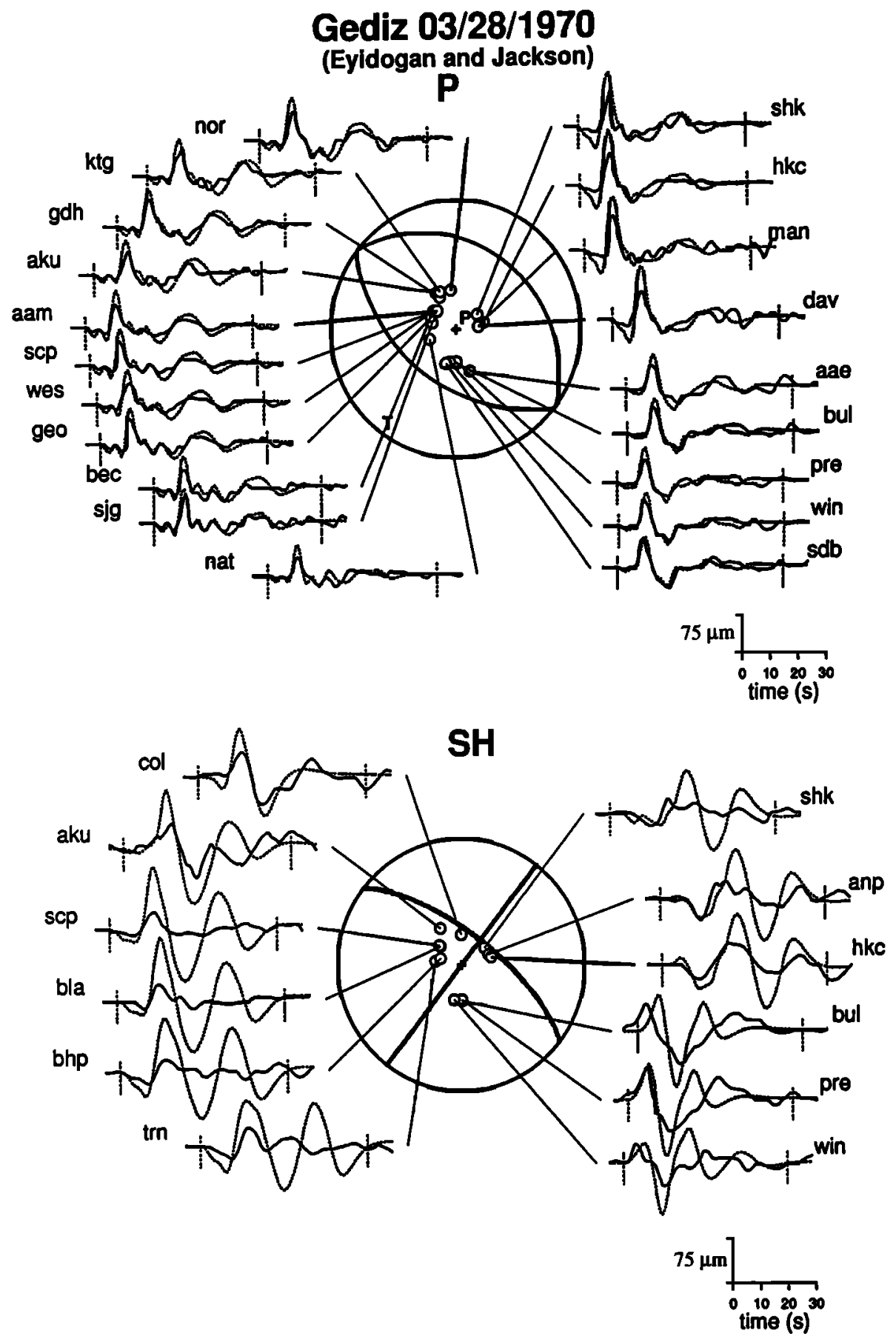

Figure 5. $P$ and $S H$ waveform fit for the Gediz earthquake for Eyidogan and Jackson's [1985] rupture model. Seismogram amplitudes are normalized to an epicentral distance of $40^{\circ}$.

following Huang et al. [1986] and Nábělek (submitted manuscript, 1995). The test as applied underestimates the total number of degrees of freedom in the data resulting in a conservative estimate of the bounds. The bounds are presented as the maximum curvature (calculated in $10^{\circ}$ increments) that cannot be rejected by the $t$ test at $95 \%$ confidence level.

The resolution of the depth distribution of slip comes from the information contained in amplitudes and polarities (radiation patterns) of the direct arrivals and the free surface reflections comprising the $P$ and $S$ waveforms. The procedure works best for faults with a large fault width $(15-20 \mathrm{~km})$. This guarantees that contributions from different parts of the fault are well separated in time on the seismograms. Fault curvature for earthquakes with very shallow centroids, implying a small fault width, is more difficult to detect.

An additional estimate of fault geometry comes from comparing first-motion fault plane solutions from shortperiod seismograms with point source solutions from modeling of long-period waveforms. First-motion solutions provide information about the fault orientation at the nucleation point (hypocenter, generally the bottom of the fault), whereas longperiod waveform modeling provides the centroidal (average) source parameters. 


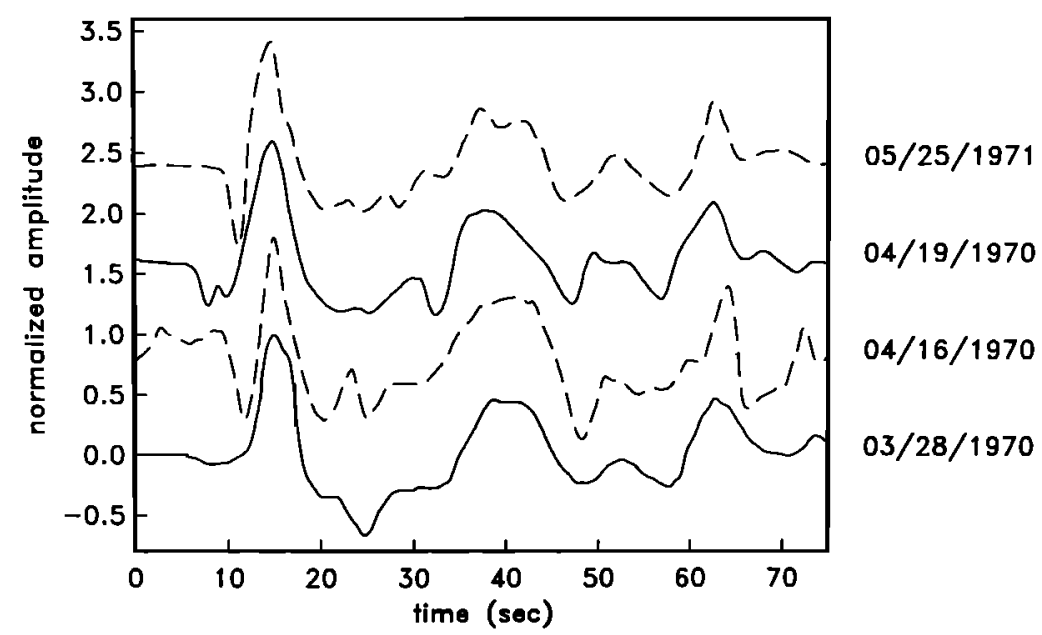

Figure 6. $P$ wave seismograms observed at station Addis Ababa, Ethiopia (AAE) for the Gediz mainshock (bottom trace) and three large aftershocks $\left(M_{w} \geq 5.5\right)$. The similarity in waveshapes, especially of the latearriving phases (about $35 \mathrm{~s}$ and $60 \mathrm{~s}$ into the seismograms) indicates the waveform complexity is caused by structural effects.

\section{Results From Earthquakes}

As an example we present analysis of the $M_{w}=7.1,1970$, Gediz, Turkey earthquake, the largest event of this study. The point source solution (Figure 4) gives the fault orientation (strike, $304^{\circ}$; dip, $41^{\circ}$; and rake, $263^{\circ}$ ) that agrees well with the orientation obtained by McKenzie [1978] from firstmotion polarities of long-period WWSSN data. The centroid depth is $7.7 \mathrm{~km}$, and the seismic moment is $5.1 \times 10^{19} \mathrm{~N} \mathrm{~m}$. The dip of the first-motion fault plane solution, derived from short-period seismograms by the authors, is compatible with the dip obtained from waveform inversion indicating no significant change in fault dip between hypocenter and centroid.

Adding a low-angle detachment-type source (strike, $304^{\circ}$; and rake, $270^{\circ}$ ) at $15.4 \mathrm{~km}$ depth, twice the centroid depth, we find only minor moment release $(<10 \%$ of point source moment release) distributed over $40 \mathrm{~s}$. The improvement to the waveform fit is insignificant, contrary to the conclusion reached by Eyidogan and Jackson [1985]. It should be pointed out, however, that our model does not explain several latearriving phases in $P$ wave seismograms from stations located in Africa and North America, which Eyidogan and Jackson [1985] interpreted as resulting from seismic slip on a basal detachment. Examining the complex faulting model proposed by Eyidogan and Jackson [1985] (Figure 5), we find that it actually decreases the fit of the $P$ wave amplitudes (e.g., stations SHK, HKC, MAN, and DAV) and fails completely to match the observed $S H$ seismograms. It is therefore understandable that our inversion rejected the detachment-type model as unacceptable. We believe the $P$ waveform complexities observed at African and North American stations are a

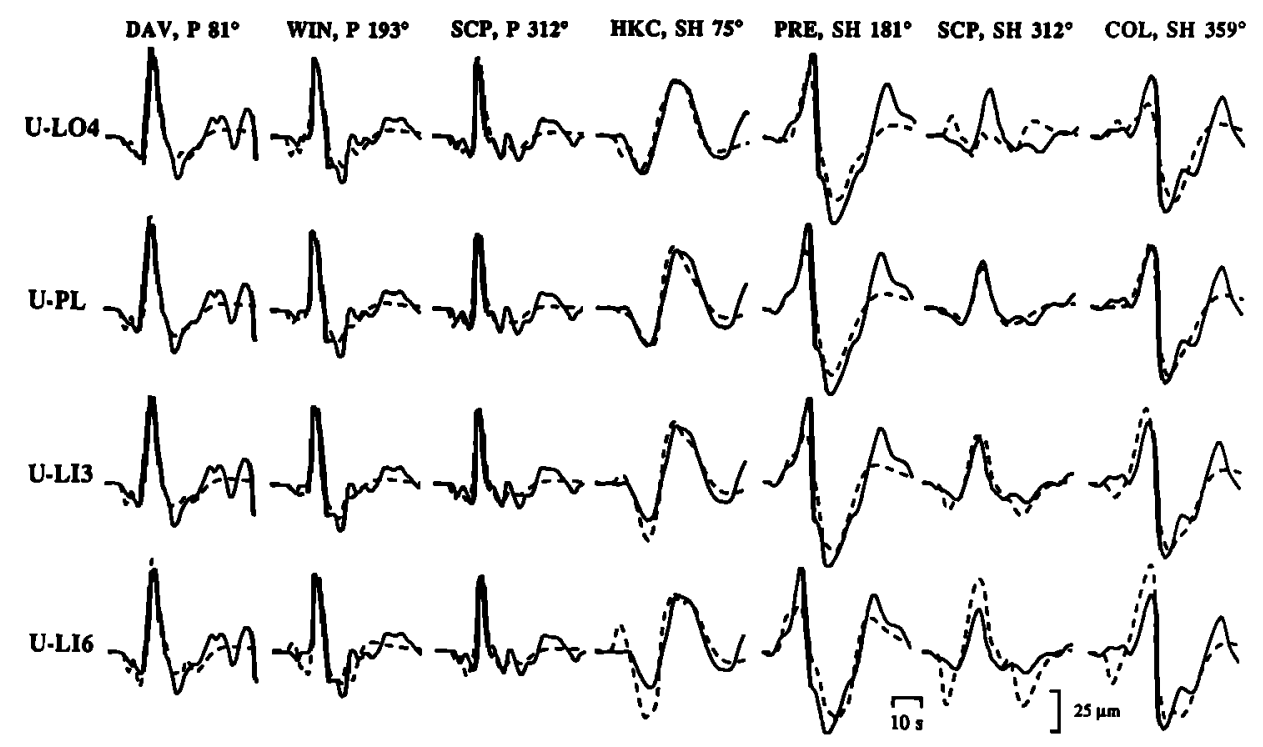

Figure 7. Comparison of $P$ and $S H$ waveforms from the Gediz earthquake from several azimuthally distributed stations for models with different fault curvature. Solid lines indicate observed seismograms; dashed lines indicate synthetic seismograms. Model LO4 has $40^{\circ}$ convex curvature, PL is planar, LI3 has $30^{\circ}$ concave curvature, and LI6 has $60^{\circ}$ concave curvature. Event-station azimuth is given next to station ID. 
Table 1. Summary of Source Parameters and Downdip Fault Geometry of Investigated Earthquakes

\begin{tabular}{|c|c|c|c|c|c|c|c|c|}
\hline Event and Date & $\begin{array}{l}\text { Strike, } \\
\text { deg }\end{array}$ & $\begin{array}{l}\text { Dip, } \\
\text { deg }\end{array}$ & $\begin{array}{c}\text { Rake, } \\
\text { deg }\end{array}$ & $10^{17}{ }_{\mathrm{N}}^{\prime \prime}$ & $\begin{array}{l}\text { Depth, } \\
\text { km }\end{array}$ & $\begin{array}{l}\text { Curvature, } \\
\text { deg }\end{array}$ & $\begin{array}{c}\text { 95\% Bounds, } \\
\text { deg }\end{array}$ & $\begin{array}{l}\text { First-Motion Bounds, } \\
\text { deg }\end{array}$ \\
\hline Gediz, March 28, 1970 & 304 & 41 & 263 & 505 & 7.7 & 0 & $-0 /+0$ & 0 \\
\hline Corinth, Feb. 24, 1981 & 268 & 39 & 284 & 105 & 8.6 & 0 & $-10 /+10$ & $-10 /+5$ \\
\hline Thessalonıki, June 20, 1978 & 257 & 41 & 264 & 35 & 7.0 & 0 & $-20 /+30$ & 0 \\
\hline Corinth, Feb. 25, 1981 & 246 & 44 & 276 & 35 & 6.7 & 0 & $-50 /+30$ & $-15 /+5$ \\
\hline Corinth, March 4, 1981 & 50 & 45 & 264 & 23 & 5.6 & 0 & $-30 /+30$ & $-10 /+5$ \\
\hline Alasehir, March 28, 1969 & 300 & 41 & 263 & 129 & 3.3 & 20 & $-10 /+40$ & -2 \\
\hline
\end{tabular}

Strike, dip, and rake indicate point source fault plane orientation. $\boldsymbol{M}_{\boldsymbol{\sigma}}$ is seismic moment. Depth is centroid depth. Curvature is curvature of the best fit model (positive, convex upward). The $95 \%$ bounds indicate maximum curvature ( $10^{\circ}$ increments) that cannot be rejected by $t$ test at $95 \%$ confidence level. First-motion bounds indicate maximum allowable difference in fault dip between first-motion data and centroidal solution (positive, fault dip increasing with depth); in no case, was curvature required by this test.

result of structural effects along those ray paths since main shock and aftershock waveshapes are similar (Figure 6).

To investigate the downdip curvature of the fault on which this earthquake occurred, we distributed three subsources along the fault's width at $2.6,7.7$, and $12.8 \mathrm{~km}$ depth. The fault models with different amounts of prescribed curvature (in $10^{\circ}$ increments) are compared. Figure 7 shows the fit to the waveforms for azimuthally representative stations for four models: planar (PL), concave upward with $30^{\circ}$ and $60^{\circ}$ curvature (LI3, and LI6), and convex upward with $40^{\circ}$ curvature (LO4). The planar model (PL) has the smallest misfit overall and consistently fits better than any listric model. As expected from the synthetic example shown in Figure 2, the main differences between models can be seen for $S H$ waves (e.g., SCP, COL). Applying a statistical $t$ test, we find that, at the $95 \%$ level of confidence, models with a change in fault dip as small as $10^{\circ}$ are not allowed by the data.

The above evidence indicates that the fault plane of the Gediz earthquake is essentially planar. We find no evidence for leveling of the fault onto a basal detachment or for coseismic slip associated with a detachment.

We applied the same three-step modeling procedure to all six investigated earthquakes. Details of the analysis are given by Braunmiller [1991]. Table 1 summarizes the results. The results indicate the dominant normal-faulting involved ruptures along steeply dipping planar fault surfaces. In no case did we find significant evidence for coseismic slip along a basal detachment.

The Gediz earthquake and the main shock of the Corinth sequence are the largest of the investigated earthquakes with well-constrained fault geometry. The centroid depth (hence the fault width) for these two events is larger than for the other earthquakes, and therefore the resolution of the downdip curvature of these two events is better. They ruptured along essentially planar faults. For the Thessaloniki and the two later shocks of the Corinth sequence, planar geometry fits the waveforms better than any listric model. However, misfit differences are smaller, resulting in a much larger uncertainty. A comparison of the centroidal solution with the first-motion polarities favors planar models for these earthquakes.

The Alasehir earthquake is the only event we studied where the best fitting model based on waveform data is slightly curved. Because its centroid depth is only $3.3 \mathrm{~km}$, this earthquake's fault geometry is least resolved. A $20^{\circ}$ convex upward curvature fits slightly, although statistically insignificantly, better than the planar model. On the other hand, listric geometry (concave upward curvature), which is geologically more feasible than convex upward curvature, is not supported by the data. The consistency of the short-period first-motion mechanism and the centroidal solution favors a planar model for this earthquake as well.

\section{Conclusions}

We have shown that good station coverage and a sensitive statistical test, such as the one presented here, are required to detect the small amplitude variations in teleseismic body waves caused by fault curvature. It is crucial to include $S H$ waves, since their waveforms are most sensitive to changes in fault dip for dip-slip sources.

The large earthquakes studied here generated surface ruptures. Their fault widths indicate that they were powerful enough to rupture the entire width of the seismogenic upper crust. These earthquakes occurred on main range-bounding faults that at present contribute considerably to continental extension. Resolving the geometry of these faults constrains acceptable models of extension for this region.

Our analysis indicates that in the brittle seismogenic part of the crust, the large range-bounding faults are essentially

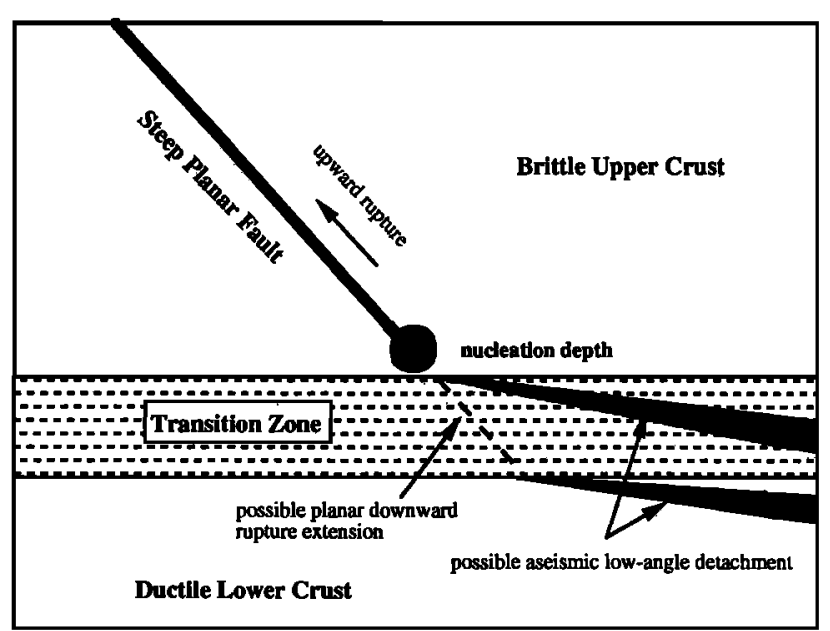

Figure 8. Sketch of rupture scenario on a large continental normal fault consistent with our observations. Rupture in the seismogenic layer occurs on a steeply dipping planar fault and propagates upward from the bottom of the brittle crust. For some large earthquakes, rupture may extend into the transition zone. Detachment of brittle, upper crust from plastic, lower crust occurs aseismically. 
planar along the entire fault width. We found no significant evidence for seismogenic involvement of the detachment at the base of the upper crust. Figure 8 sketches a rupture scenario for large continental normal faults consistent with our results. Rupture nucleates at the bottom of the brittle upper crust and propagates upward along a steeply dipping planar fault. There is a possibility of planar extension of the coseismic faulting into the transition zone [Scholz, 1988; Nábělek, submitted manuscript, 1995]. The decoupling of the upper crust from the lower, plastic crust occurs aseismically in the plastic lower crust or the transition zone.

Acknowledgments. Supported by National Science Foundation grant EAR-8816920. J. Dewey and D. Doser reviewed the manuscript.

\section{References}

Barrientos, S. E., R. S. Stein and S. N. Ward, Comparison of the 1959 Hebgen Lake, Montana and the 1983 Borah Peak, Idaho earthquakes from geodetic observations, Bull. Seismol. Soc. Am., 77, 784-808, 1987.

Braunmiller, J., Down-dip geometry and depth extent of normal faults in the Aegean - Evidence from earthquakes, M. Sc. thesis, 225 pp., Oreg. State Univ., Corvallis, 1991.

Buck, W. R., Flexural rotation of normal faults, Tectonics, 7, 959-973, 1988.

Buck, W. R., F. Martinez, M. S. Steckler and J. R. Cochran, Thermal consequences of lithospheric extension: Pure and simple, Tectonics, 7, 213-234, 1988.

Crittenden, M. D., Jr., P. J. Coney and G. H. Davis, (Eds.), Cordilleran Metamorphic Core Complexes, Mem. Geol. Soc. Am., 153, 490 pp., 1980.

Das, S. and C. Scholz, Why large earthquakes do not nucleate at shallow depths, Nature, 305, 621-623, 1983.

Davis, G. A., J. L. Anderson, E. G. Frost and T. J. Shackelford, Mylonitization and detachment faulting in the Whipple-BuckskinRawhide Mountains terrane, southeastern California and western Arizona, in Cordilleran Metamorphic Core Complexes, edited by $\mathbf{M}$. D. Crittenden Jr., P. J. Coney, and G. H. Davis, Mem. Geol. Soc. Am., 153, 79-130, 1980.

Davis, G. H., Shear-zone model for the origin of metamorphic core complexes, Geology, 11, 342-347, 1983.

Doser, D. I., Earthquake processes in the Rainbow Mountain-Fairview Peak-Dixie Valley, Nevada, region 1954-1959, J. Geophys. Res., 91, 12,572-12,586, 1986.

Doser, D. I., and R. B. Smith, An assessment of source parameters of earthquakes in the Cordillera of the western United States, Bull. Seismol. Soc. Am., 79, 1383-1409, 1989.

Eyidogan, H., and J. Jackson, A seismological study of normal faulting in the Demirci, Alasehir and Gediz earthquakes of 1969-1970 in western Turkey: Implications for the nature and geometry of deformation in the continental crust, Geophys. J. R. Astron. Soc., 8I, 569$607,1985$.
Forsyth, D. W., Finite extension and low-angle normal faulting, Geology, 20, 27-30, 1992.

Hamblin, W. K., Origin of "reverse drag" on the downthrown side of normal faults, Geol. Soc. Am. Bull., 76, 1145-1164, 1965.

Huang, P. Y., S. C. Solomon, E. A. Bergman, and J. L. Nábĕlek, Focal depths and mechanisms of Mid-Atlantic ridge earthquakes from body wave inversion, J. Geophys. Res., 91, 579-598, 1986.

Jackson, J. A., and D. McKenzie, The geometrical evolution of normal fault systems, J. Struct. Geol., 5, 471-482, 1983.

Jackson, J. A., and N. J. White, Normal faulting in the upper continental crust: Observations from regions of active extension, J. Struct. Geol., II, 15-36, 1989.

Lister, G. S., M. A. Etheridge and P. A. Symonds, Application of detachment fault model to the formation of passive continental margins, Geology, 14, 246-250, 1986.

McKenzie, D. P., Active tectonics of the Alpine-Himalaya belt: The Aegean Sea and surrounding regions, Geophys. J. R. Astron. Soc , $55,217-254,1978$.

Melosh, H. J., Mechanical basis for low-angle normal faulting in the Basin and Range province, Nature, 343, 331-335, 1990.

Morton, W. H., and R. Black, Crustal attenuation in Afar, in Afar Depression of Ethiopia, vol. 1, edited by A. Pilger and A. Rössler, pp. 55-65, Schweizerbart., Stuttgart, Germany, 1975.

Nábělek, J. L., Determination of earthquake source parameters from inversion of body waves, Ph. D. thesis, 361 pp., Mass. Inst. of Technol., Cambridge, 1984.

Scholz, C. H., The brittle-plastic transition and the depth of seismic faulting, Geol. Rundsch., 77, 319-328, 1988.

Sibson, R. H., Fault zone models, heat flow, and the depth distribution of earthquakes in the continental crust of the United States, Bull. Seismol. Soc. Am., 72, 151-163, 1982.

Sibson, R H., A note on fault reactivation, J. Struct. Geol., 7, 751-754, 1985.

Spencer, J. E., and C. G. Chase, Role of crustal flexure in initiation of low-angle normal faults and implications for structural evolution of the Basin and Range province, J. Geophys. Res., 94, 1765-1775, 1989.

Stein, R. S., and S. E. Barrientos, Planar high-angle faulting in the Basin and Range: Geodetic analysis of the 1983 Borah Peak, Idaho earthquake, J. Geophys. Res., 90, 11,355-11,366, 1985.

Wallace, M. H., and J. Kemeny, Nucleation and growth of dip-sipp faults in a stable craton, J. Geophys. Res., 97, 7145-7157, 1992.

Wernicke, B., Low-angle normal faults in the Basin and Range province: Nappe tectonics in an extending orogen, Nature, 291, 645$648,1981$.

Wernicke, B., and G. J. Axen, On the role of isostasy in the evolution of normal fault systems, Geology, 16, 848-851, 1988 .

Wernicke, B., and B. C. Burchfiel, Modes of extensional tectonics, $J$. Struct. Geol., 4, 105-115, 1982.

J. Braunmiller and J. Nábĕlek, College of Oceanic and Atmospheric Sciences, Oregon State University, 104 Oceanography Administration Building, Corvallis, OR 97331-5503. (e-mail: jbraunmi@oce.orst.edu; jnabelek@oce.orst.edu)

(Received June 8, 1995; revised September 11, 1995; accepted September 15, 1995.) 